\title{
Influence of Graphite Content on Corrosion Behavior of Cartridge Brass in a 3.5 wt. \% NaCl Solution
}

\author{
Mohammed Ali Almomani, Wail Radwan Tayfour, Mohammed Hani Nimrat \\ Industrial Engineering Department, Jordan University of Science and Technology, P. O. Box 3030, \\ Irbid 22110, Jordan. \\ *E-mail: maalmomani7@ just.edu.jo
}

doi: $10.20964 / 2016.06 .30$

Received: 22 October 2015 / Accepted: 6 January 2015 / Published: 4 May 2015

Several cartridge brass $(\mathrm{Cu}-30 \mathrm{Zn})$ metal matrix composites reinforced with different weight fractions of graphite (Gr) particles were fabricated using the powder metallurgy (PM) method. Potentiodynamic testing was used to examine the corrosion behavior of both base monolithic alloy and composites in a simulated sea water solution $(3.5 \mathrm{wt} \% \mathrm{NaCl}$ solution). The results revealed that $\mathrm{Cu}-30 \mathrm{Zn}$ reinforced with active graphite particles shows a higher tendency to uniform corrosion as compared to the corresponding monolithic matrix alloy; due to the strong microgalvanic couple between conductive graphite particles and matrix material, and also the increase of cathodic area with increase of graphite weight fractions. The electrochemical results also shows the increase of efficiency of corrosion products layer after transpassive dissolution stage. This is due to the formation of crevice regions at the particle matrix interface which impede propagation of pits into the matrix. Both morphology and elemental analysis of the samples' surfaces before and after testing were examined using Scanning Electron Microscope (SEM) that is equipped with Energy Dispersive Spectroscopy (EDAX) system. The corroded surface of the composites is covered with the corrosion byproduct layer with large number of small shallow pits. This result is consistent with negative hysteresis attained at electrochemical testing.

Keywords: Uniform; Localized corrosion; Galvanic corrosion; Metal matrix composite; Cartridge brass; Graphite.

\section{FULL TEXT}

(C) 2016 The Authors. Published by ESG (www.electrochemsci.org). This article is an open access article distributed under the terms and conditions of the Creative Commons Attribution license (http://creativecommons.org/licenses/by/4.0/). 